\title{
The Impact of a Cultural Research Course Project on Foreign Language Students' Intercultural Competence and Language Learning
}

\author{
Fang Li \\ Xi'an International Studies University, Xi'an, China \\ Yingqin Liu \\ Cameron University, Lawton, USA
}

\begin{abstract}
This study explores whether using a cultural research course project can positively impact foreign language students' intercultural competence and language learning. Using a case study method, the researchers recruited 12 student participants from an Intermediate Mandarin Chinese I class and from an Introduction to Mandarin Chinese I class in the Fall 2014 semester at a small public southwest university in USA. The project asked the participants to do a PowerPoint oral presentation on special topics from the target language culture and then to write a reflective cultural comparison English essay on this learning experience during the final exam. The findings show that, through doing the project, the students have improved their intercultural competence in that they have a more positive attitude towards "otherness," enriched their cultural knowledge of the target language society and that of their own, and obtained skills in critically appreciating and evaluating both similarities and differences between the target language culture and their own. The students also expanded their language learning experience beyond the classroom and textbook and acquired better language skills in listening, speaking, and writing Chinese characters while they became more interested in and motivated by learning the target language and culture. Recommendations for future study are discussed.
\end{abstract}

Index Terms - foreign language education, intercultural competence, course cultural research project, Mandarin Chinese

\section{INTRODUCTION}

As globalization further expands its influences on the $21^{\text {st }}$ century economy, culture, and education, foreign language teachers have realized that their students will work and interact with people of diverse cultures and will have to be able to communicate effectively across boundaries that are not merely linguistic. Just as Catrinel (2011) explains that learning a foreign language goes beyond the mere development of four basic skills ( listening, speaking, reading and writing), and it is also about enlarging individual boundaries, opening new perspectives, providing explanations for different social, cultural realities, and demonstrating understanding and respect for people from other cultures. Furstenberg (2010) argues that the goal of foreign language teaching should no longer be limited to helping students develop and achieve linguistic and communicative competence, but it should include developing students' intercultural competence To emphasize this goal, Kramsch (1993) states that language should be taught as a cultural practice, and instructors should provide learners with opportunities to develop intercultural understanding and critically examine stereotypes by objectively analyzing target culture and their own.

According to The Standards for Foreign Language Learning for the $21^{\text {st }}$ Century (National Standards, 2006) in the USA, three out of the five foreign language learning objectives emphasize communication, culture, and comparison. These cultural objectives involve students' being able to demonstrate an awareness of the relationships among the practice, products, and perspectives of the target culture and to understand the concept of culture development through comparison between the target culture and their native culture.

These national standards of foreign language education in USA in the $21^{\text {st }}$ century highlight the importance of taking an intercultural orientation to teaching languages, which encourages students to analyze and reflect on the significance or meanings of similarities and differences between the target language culture and their own culture(s). In so doing, as Scarino (2010) claims, students decenter from their linguistic and cultural world to consider their own situatedness from the perspective of another and learn to constantly move between their linguistic and cultural world and that of the users of the target language. In this process, students gradually come to understand culture not only as information about diverse people and their practices but also, and most importantly, as the contextual framework that people use to exchange meaning with others and through which they understand their social world (Scarino, 2010). This intercultural learning process will certainly help prepare each student to become what Byram \& Zaratethe (1997) and Kramsch (1998) call an "intercultural speaker/mediator" (p.17), who has the ability to interact with 'others', to accept other perspectives 
and perceptions of the world, to mediate different perspectives, and to be conscious of their evaluations of differences (Byram, Nichols, \& Stevens, 2001). However, to become such an intercultural speaker/mediator, Byram et al (2001) believe that students clearly need both linguistic competence and intercultural competence composed of "knowledge, skills, and attitudes, complemented by the values one holds" (p. 5).

So, foreign language teachers need to provide learning opportunities to help students acquire intercultural competence as well as linguistic competence. Byram \& Morgan (1994) point to the important role language education can play, suggesting that teachers can, in fact, have influence over cognitive, affective, and moral development, and thereby play a significant role in young people's education. Hoff (2013) also expresses this sentiment, stating that "teachers should make the interrelationship of language and culture an explicit topic for discussion and reflection in the FL classroom, as this could be a significant contributing factor to the development of the learners' intercultural competence" (p.30). However, as many educators of foreign languages have noted, the big question is how we, as language teachers, can improve our students' intercultural competence through foreign language teaching and learning. In order to contribute to the ongoing discussion of this important issue, this paper presents a case study that embedded cultural teaching and learning in a target culture course research project to help develop language students' intercultural competence in college level Mandarin Chinese classes.

\section{THEORETICAL FRAMEWORK}

\section{A. Definition of Intercultural Competence in the Context of Foreign Language Education}

According to The Common European Framework of References for Languages (Council of Europe, 2001), intercultural competence in foreign language learning refers to the ability to establish a relationship between the native culture and a foreign culture, raise cultural sensitivities, use varied strategies to establish contact with people from another culture, and to efficiently handle situations comprised of cultural misunderstanding and conflicts. This definition emphasizes the idea that cultural knowledge and intercultural awareness are essential aspects of language learning, specifically linked to the promotion of personal development.

Bryam (1997) introduced "A Model of Intercultural Communication Competence" to the field of foreign language education, which privileges intercultural competence in foreign language education. Catrinel (2011) states that Bryam's intercultural competence has been perceived as the guiding concept for the overall aim of foreign language education. Hoff (2013) further points out that Bryam's influential contribution to this field suggests that a nuanced understanding of intercultural competence is essential.

Indeed, Bryam's model for educational action in the FL classroom identifies five aspects of intercultural learning, which should be cultivated if students are to develop such intercultural competence (also see Figure 1):

- Attitudes (savoir-être)

- Knowledge (savoir)

- Skills of interpreting and relating (savoir-comprendre)

- Skills of discovery and interaction (savoir-apprendre/-faire)

- Critical cultural awareness (savoir-s'engager) (Byram, 2009, p. 323). 


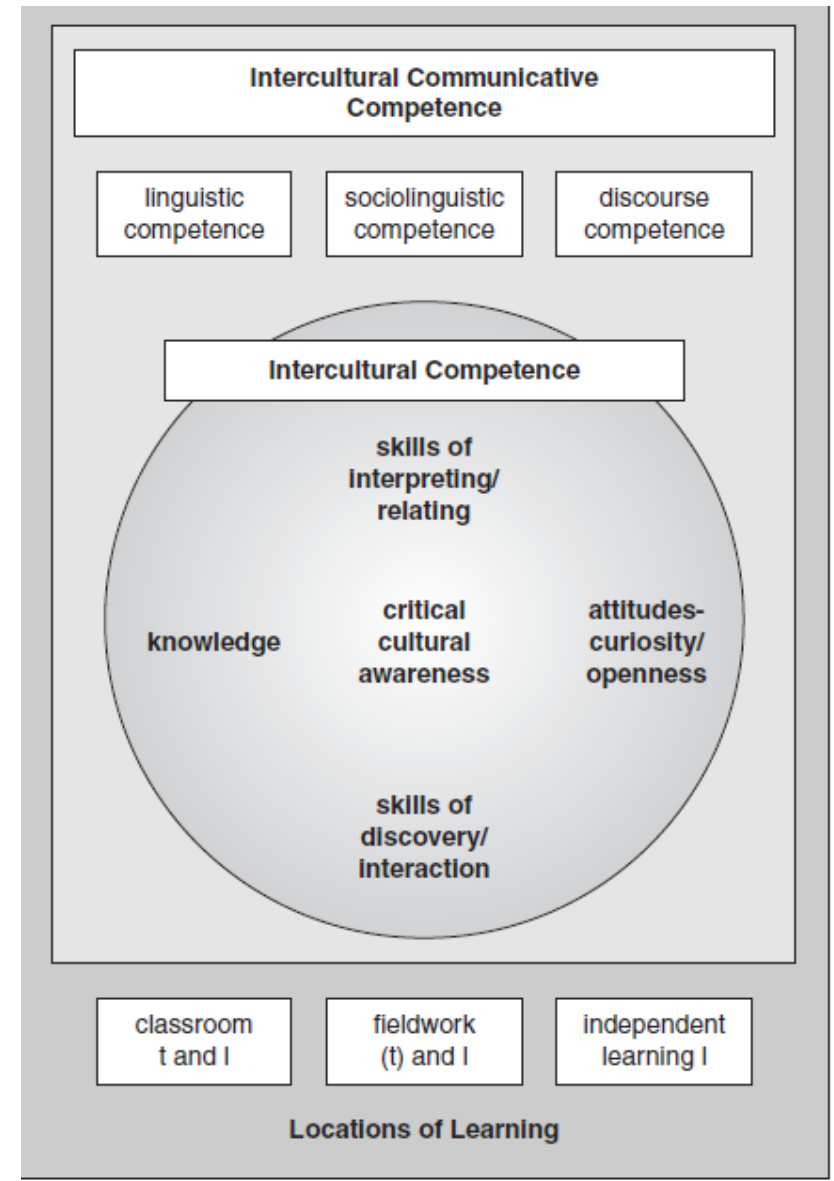

Figure 1. A Model of Intercultural Communicative Competence (Bryam, 2009).

For the purpose of distinguishing "A Model of Intercultural Communicative Competence" from the approach of imitating the native speaker as a basis for teaching linguistic competence, Bryam (2009) introduces the concept of the 'intercultural speakers/mediators' in this new approach. Among the five aspects in the model, "[t]he foundation of intercultural competence is in the attitudes of the intercultural speaker and mediator" (Bryam, 2009, p. 5). Bryam's intercultural speaker/ mediators approach other cultures with 'curiosity and openness,' and a "readiness to suspend disbelief about other cultures and belief about one's own" so that they will acquire "the ability to "decenter" (Bryam, 2009, p.5). "Another crucial factor is knowledge," and the intercultural speakers/mediators possess the knowledge "of social groups and their products and practices" as well as "the general processes of societal and individual interaction" (Bryam, 2009, p.5-6). Then, there are the two aspects of skills. Bryam (2009) emphasizes "the ability to interpret a document or event from another culture, to explain it and relate it to documents from one's own" (p. 5). He also highlights the significance of being able to "acquire new knowledge of a culture and cultural practices" (Bryam, 2009, p.6) and to "operate knowledge, attitudes and skills [in] real-time communication and interaction" (Bryam, 2009, p.6). Finally, Bryam (2009) points out that the intercultural speakers/mediators are able to critically evaluate "practices and products in one's own and other cultures and countries" (p. 6); thus, they can "become more aware of their own values and how these values influence their views of other people's values" (p.7). So, it is evident that intercultural competence for Bryam's (2009) model is composed of a language learner's attitudes, knowledge, skills, and critical cultural awareness in a dynamic foreign language education context.

\section{B. A Working Definition of Intercultural Competence for this Study}

Educators who study the teaching of intercultural competence have embraced Bryam's model (Hoff, 2013). Likewise, the present study uses a working definition of intercultural competence for foreign languages informed by Bryam's (2009) model. The intercultural competence for a foreign language learner means:

1) the ability to decenter from one's own cultural values, beliefs, and behaviors while being able to appreciate and respect perspectives of "outsiders" from other cultures

2) the capability of knowing both social processes and illustrations of those processes and products for one's own culture and others'

3) the ability to interpret and relate different cultural practices and perspectives via comparison and to discover and interact with the new things in the process of intercultural language learning experiences

4) the ability to critically evaluate and reflect on the target language culture and their own native culture 


\section{METHOD}

\section{A. Research Questions}

1. Can a cultural research project in a language course help improve foreign language students' intercultural competence?

2. Can this course cultural research project help promote the students' language skills?

\section{B. Participants and Settings}

The present paper presents a case study that lasted four weeks. The participants were 3 students from an Intermediate Mandarin Chinese I class and 9 students from an Introduction to Mandarin Chinese I class in the Fall 2014 semester at a small public southwest university in USA. First, all were given four weeks' time to create a 15 minute-oral PowerPoint presentation on a Chinese cultural topic research project. Later, they were asked to write a reflective essay in English about this cultural learning experience during their final exam.

\section{The Cultural Topic Course Research Project/Assignment}

During November 2014, the project was assigned to the student participants. The following is the assignment descriptions the researchers created:

Instructions:

Part I: 1). Choose a topic from Chinese culture and prepare a 15 minute-oral PowerPoint presentation in both English and Chinese to the whole class. 2). Compare the chosen topic to something analogous in your native culture. 3 ). Please include at least five outside sources from your research and do MLA style documentation for your PowerPoint presentation.

Part II: You will write a reflective comparison essay about the cultural topic from this research project during the final exam.

\section{Procedures}

Stage 1: At the beginning of November 2014, the student participants were given four weeks' time to conduct their research on their chosen cultural topics and to create their PowerPoint presentations.

Stage 2: At the end of the November 2014, students did individual oral presentations on their Chinese cultural research projects.

Stage 3: At the beginning of December 2014 during the final exams for the two Chinese classes, the participants were requested to write reflective cultural comparison English essays based on their learning experience of this Chinese cultural topic research project and also to use their general cultural learning from their Chinese classes.

\section{E. Data Collection and Instruments}

Two types of research data were collected by the researchers. The first one was from 12 student participants' PowerPoint oral presentations on the cultural research project (see the assignment description in the section $\mathrm{C}$ as the instrument).

The second type was from 12 student participants' reflective cultural comparison English essays in their final exams. The writing prompt (the instrument) for the final exam (the researchers created it) read:

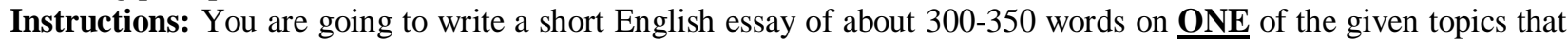
compare Chinese culture with American Culture, or you can choose your own topic:

- Chinese Spring Festival holiday and the American Christmas holiday

- Chinese Mid-Autumn Moon Festival and the American Thanksgiving holiday

- Tea in Chinese culture and Coffee in American Culture

- The New Year's Day Celebration in Chinese culture and in American culture

In your essay, you should discuss the following aspects:

- Clearly identify at least two differences about the chosen cultural topic

- Clearly articulate at least two similarities regarding the chosen cultural topic,

- Analyze your comparison through using examples and details, and explain why you think the similarities and/ or differences exist.

- Finally, conclude with at least two positive things you have learned from this comparison between Chinese culture and American culture.

\section{FINDINGS AND DisCUSSION}

This section will present the results and discussion on the study in the form of responding to the two research questions presented in the beginning.

\section{A. Findings for and Discussion on Research Question 1}

Research Question 1: Can a cultural research project in a language course help improve foreign language students' intercultural competence? 
The findings from the student oral presentations and their reflective cultural comparison essays in the final exam help to answer this research question.

First, we will discuss the findings from student PowerPoint oral presentations on the Chinese cultural topics (Part I of the Cultural Topic Course Research Project/Assignment). From the data analysis on the PowerPoint presentations, we summarize and classify the findings into three categories (see TABLE 1).

TABLE 1

SUMMARY OF Findings From STUDENT POWERPOINT ORAL PRESENTATIONS ON THE CUltural PROJECT

\begin{tabular}{|c|c|c|}
\hline $\begin{array}{l}\text { 1. Cultural Topics from the Student PPT } \\
\text { Oral Presentations }\end{array}$ & $\begin{array}{l}\text { 2. Main Bi-Cultural Knowledge Student } \\
\text { Learned from the PPT Oral Presentations }\end{array}$ & $\begin{array}{l}\text { 3. The Target Language Skills Reinforced } \\
\text { through the PPT Oral Presentations }\end{array}$ \\
\hline Chinese Medicine and Western Medicine & $\begin{array}{l}\text { Origins and principles/ theories of medicines } \\
\text { from both cultures }\end{array}$ & $\begin{array}{l}\text { Oral Chinese, new vocabulary, and Written } \\
\text { Chinese Pinyin and Chinses Characters }\end{array}$ \\
\hline Chinese Opera and Western Opera & $\begin{array}{l}\text { Histories, costumes, and music from both } \\
\text { cultures }\end{array}$ & $\begin{array}{l}\text { Oral Chinese, new vocabulary, and Written } \\
\text { Chinese Pinyin and Chinses Characters }\end{array}$ \\
\hline Tea in China and Coffee in America & $\begin{array}{l}\text { Histories, beliefs, and social occasions from } \\
\text { both cultures }\end{array}$ & $\begin{array}{l}\text { Oral Chinese, new vocabulary, and Written } \\
\text { Chinese Pinyin and Chinses Characters }\end{array}$ \\
\hline $\begin{array}{l}\text { Chinese Spring Festival and American } \\
\text { Christmas Holiday }\end{array}$ & $\begin{array}{l}\text { Origins, beliefs, customs, and ways of } \\
\text { celebrations from both cultures }\end{array}$ & $\begin{array}{l}\text { Oral Chinese, new vocabulary, and Written } \\
\text { Chinese Pinyin and Chinses Characters }\end{array}$ \\
\hline $\begin{array}{l}\text { Chinese Mid-Autumn Moon Festival and } \\
\text { American Thanksgiving Holiday }\end{array}$ & $\begin{array}{l}\text { Origins, beliefs, customs, and ways of } \\
\text { celebrations from both cultures }\end{array}$ & $\begin{array}{l}\text { Oral Chinese, new vocabulary, and Written } \\
\text { Chinese Pinyin and Chinses Characters }\end{array}$ \\
\hline $\begin{array}{l}\text { Chinese Way of Addressing People and } \\
\text { American Way of Addressing People on } \\
\text { Different Occasions }\end{array}$ & $\begin{array}{l}\text { Traditions, beliefs, and social occasions from } \\
\text { both cultures }\end{array}$ & $\begin{array}{l}\text { Oral Chinese, new vocabulary, and Written } \\
\text { Chinese Pinyin and Chinses Characters }\end{array}$ \\
\hline Chinese Fashion and American Fashion & $\begin{array}{l}\text { History, customs, and social occasions from } \\
\text { both cultures }\end{array}$ & $\begin{array}{l}\text { Oral Chinese, new vocabulary, and Written } \\
\text { Chinese Pinyin and Chinses Characters }\end{array}$ \\
\hline Chinese and American String Instruments & $\begin{array}{l}\text { Histories, music, technique, and social } \\
\text { occasions from both cultures }\end{array}$ & $\begin{array}{l}\text { Oral Chinese, new vocabulary, and Written } \\
\text { Chinese Pinyin and Chinses Characters }\end{array}$ \\
\hline $\begin{array}{l}\text { Popular Chinese Foods and Popular } \\
\text { American Foods }\end{array}$ & $\begin{array}{l}\text { Traditions, customs, and health concerns from } \\
\text { both cultures }\end{array}$ & $\begin{array}{l}\text { Oral Chinese, new vocabulary, and Written } \\
\text { Chinese Pinyin and Chinses Characters }\end{array}$ \\
\hline
\end{tabular}

The first two categories (cultural topics and knowledge learned) in TABLE 1 demonstrate that the project encourages students to study the target language culture beyond the classroom. In many college introductory and intermediate level Chinese classes, learning about culture would usually be discussed when the subjects of the lessons being studied involve some target language traditions such as how to address people of different age groups and ways to celebrate holidays. Furthermore, the discussion time on the cultural topics would be limited due to the fact that the class focus is on linguistic competence such as understanding grammar and sentence patterns. However, the findings here reveal that when doing the PowerPoint oral presentations, the students explored nine different Chinese vs American cultural topics of their own interests in more depth, ranging from the subjects of holidays, music, and medicine to those of fashion, music instruments, drinking, and foods. Additionally, when studying each cultural topic, the students had different focus on the cultural knowledge such as its history, its theories, its practice and its development. Thus, this cultural research project has helped provide students with more opportunities to encounter Chinese culture. The project also allows an opportunity to reexamine the similar topics of their own culture in a new light of comparing them with those of Chinese culture; thus, they can acquire new perspectives on both cultures. So, based on the findings from PowerPoint oral presentations, we can say that the answer to the Research Question 1 is "YES" because the course project promoted students' intercultural competence through increasing their knowledge of both social processes defined by cultures and illustrations of those processes and products for one's own culture and others' (Bryam, 2009).

Now, we will examine and discuss the findings from students' reflective cultural comparison essays related to their oral presentation learning experiences from the final exams (Part II of the Cultural Topic Course Research Project/Assignment). The significance of connecting the oral presentation with reflective essay writing is just as Hoff (2013) claims, that after studying the cultural subjects in a public context, moving on to the reflection stage gives the students the opportunity to absorb and process new knowledge and alternative perspectives through more in-depth individual inquiry.

In fact, through analyzing the data, we can say that the findings here also provide an affirmative answer - "YES" to Research Question 1 because they demonstrate that the students' intercultural competence is improved in the three areas that are emphasized by Bryam's Model of Intercultural Communicative Competence (2009): 1) showing positive attitudes towards "otherness," 2) being able to interpret different cultural practices and perspectives and relate them to their own, and 3) being able to critically evaluate and reflect on their own cultural practice and that of others.

We use three TABLES (TABLE 2-4) to display and illustrate the findings from student participants' essays from three sample cultural topics among the five, which all support the same findings but use different examples. 
TABLE 2

THE FINDINGS FROM THE STUDENT COMPARING CULTURAL ESSAYS ON THE TOPIC OF DRINKING TEA AND DRINKING COFFEE

\begin{tabular}{|c|c|}
\hline Findings & Illustrations of Findings from Student Comparing Cultural Essays \\
\hline Topic & Comparing Drinking Tea in China with Drinking Coffee in America $(\mathrm{N}=4)$ \\
\hline $\begin{array}{l}\text { Finding } 1 \\
a \text {. Being able to decenter from } \\
\text { one's own cultural values, } \\
\text { beliefs, and behaviors while } \\
\text { appreciating and respecting } \\
\text { perspectives of "outsiders" from } \\
\text { other cultures } \\
b \text {. Being able to interpret and } \\
\text { relate different cultural practices } \\
\text { and perspectives with their own } \\
\text { via comparison and to discover } \\
\text { and interact with the new things }\end{array}$ & $\begin{array}{l}\text { "In both cultures, drinking tea and coffee is a habitual and enjoyable pastime. Both cultures use it as a way } \\
\text { to socialize..." ( Student 1) } \\
\text { "They both can bring people together in a social gathering... This can be done because both cultures value } \\
\text { relationships between people. Another aspect they share is that they are both used for relaxation. In China, } \\
\text { having a calm mind and spirit is important for health." (Student 2) } \\
\text { "..., they are surprising similar in their symbolization of each country: they are both used as ways of } \\
\text { interaction in business meetings and social events. They are also used as gifts for friends, family, and } \\
\text { coworkers." (Student } 3 \text { ) } \\
\text { "In America, coffee is used primarily as a fuel. Its caffeine content is used by Americans to get a 'jumpstart' } \\
\text { for their day. However, in China tea is used specifically for health reasons. The many different herbal teas } \\
\text { found in China have been proven to have extraordinary benefits.... So Chinese use tea for remedy." } \\
\text { (Student } 4 \text { ) } \\
\text { "One difference is that in China tea is seen as an important drink for health. But American coffee is seen as } \\
\text { unhealthy due to the sugar and caffeine." (Student 2) }\end{array}$ \\
\hline $\begin{array}{l}\text { Finding } 2 \\
\text { Being able to critically evaluate } \\
\text { and reflect on their own cultural } \\
\text { practice and that of others. }\end{array}$ & $\begin{array}{l}\text { "I learned that people in both countries love to find enjoyable ways to come together and share time with } \\
\text { each other by dirnking warm and cold beverages. And I have learned that both cultures share their ideas with } \\
\text { each other; there is a Starbucks in China and many tea cafes in America." (Student } 4 \text { ) } \\
\text { "I learned that both America and China embrace the importance of social gatherings and it was due to this } \\
\text { that these beverages became so well known." (Student 2) }\end{array}$ \\
\hline
\end{tabular}

TABLE 3

THE FINDINGS FROM THE STUDENT CULTURAL COMPARISON ESSAYS ON THE TOPIC OF CELEBRATIONS OF NEW YEARS IN CHINA AND IN AMERICA

\begin{tabular}{|c|c|}
\hline Findings & Illustrations of Findings from Student Comparing Cultural Essays \\
\hline Topic & Comparing Celebrations of New Years in China and in America ( $\mathrm{N}=3$ ) \\
\hline $\begin{array}{l}\text { Finding } 1 \\
\text { a. Being able to decenter from } \\
\text { one's own cultural values, } \\
\text { beliefs, and behaviors while } \\
\text { appreciating and respecting } \\
\text { perspectives of "outsiders" from } \\
\text { other cultures } \\
\text { b. Being able to interpret and } \\
\text { relate different cultural practices } \\
\text { and perspectives with their own } \\
\text { via comparison and to discover } \\
\text { and interact with the new things }\end{array}$ & $\begin{array}{l}\text { "On New Year's eve, both cultures like to spend time with friends and family and celebrate with foods and } \\
\text { drinks. This shows that both cultures view spending time with friends and family is important and that the } \\
\text { best time to start the New Year is to celebrate, not worry about the future." ( Student 1) } \\
\text { "Chinese celebrate it by cleaning the house and putting on decorations for luck and lightening fireworks to } \\
\text { drive bad luck away while Americans celebrate by drinking and making New Year's resolutions." "These } \\
\text { differences suggest that for the Chinese, luck plays an important role in a person's life, and people should } \\
\text { increase their good luck and decrease their bad luck. In contrast, luck doesn't play as an important role in } \\
\text { American culture, and Americans like to believe that free will alone determines the future not luck." } \\
\text { (Student 2) } \\
\text { "Another difference is that the Chinese tend to celebrate the New Year with the whole community, not just } \\
\text { with a small group of people or by themselves. In contrast, most Americans celebrate with only the people } \\
\text { closest to them or alone, not with acquaintances or neighbors. I think this is because Chinese culture is more } \\
\text { focused on the well-being of the community, while the Americans culture focuses more on the individual." } \\
\text { (student 2) } \\
\text { "Americans see the New Year as the time for them to try to make up for what they previously failed at, for } \\
\text { example, keeping their ideal weight or finally accomplishing some sort of small personal goal. Chinese New } \\
\text { Year seems more about improvements to health and prosperity. The different goals show that Chinese New } \\
\text { Year is about adding to something that is already good for sake of even better while American New Year is } \\
\text { to stabilize the bad things so the New Year can even out. Maybe, it's because 'the grass is always greener on } \\
\text { the other side?"' ( student 3) }\end{array}$ \\
\hline $\begin{array}{l}\text { Finding } 2 \\
\text { Being able to critically evaluate } \\
\text { and reflect on their own cultural } \\
\text { practice and that of others. }\end{array}$ & $\begin{array}{l}\text { From this comparison, I have learned that Chinese culture values the spirit of community, not just the } \\
\text { individual and that their traditions are kept alive, not forgotten with the passage of time. I have also learned } \\
\text { that American culture doesn't worry about the future; they just live in the moment and don't worry about } \\
\text { luck or fate." ( Student 1) } \\
\text { "I think both Chinese and American reasons for New Year are ideal: either having something good be great, } \\
\text { or fixing what you thought was wrong... I think that a hope for things to better is the same." ( Student 2) }\end{array}$ \\
\hline
\end{tabular}


TABLE 4

THE FINDINGS FROM THE STUDENT CULTURAL COMPARISON ESSAYS ON THE TOPIC OF CHINESE SPRING FESTIVAL AND AMERICAN CHRISTMAS

\begin{tabular}{|c|c|}
\hline Findings & Illustrations of Findings from Student Comparing Cultural Essays \\
\hline Topic & Comparing Chinese Spring Festival and American Christmas ( $\mathrm{N}=3$ ) \\
\hline $\begin{array}{l}\text { Finding } 1 \\
\text { a. Being able to decenter from } \\
\text { one's own cultural values, } \\
\text { beliefs, and behaviors while } \\
\text { appreciating and respecting } \\
\text { perspectives of "outsiders" from } \\
\text { other cultures } \\
b \text {. Being able to interpret and } \\
\text { relate different cultural practices } \\
\text { and perspectives with their own } \\
\text { via comparison and to discover } \\
\text { and interact with the new things }\end{array}$ & $\begin{array}{l}\text { "The Chinese spring Festival and American Christmas are all related to their religions. The Chinese honor } \\
\text { their gods and deities for bringing them protections and good luck while Americans celebrate the birth of } \\
\text { God, Jesus Christ." ( Student 1) } \\
\text { "They are similar, too. They are both times when families gather and spend time with relatives and during } \\
\text { both holidays, gifts and blessings are exchanged." ( Student 2) } \\
\text { "Both holidays have a legend behind them. Chinese Spring Festival traditionally aimed to drive away the } \\
\text { evil spirits such as 'Nian.' On Christmas tradition, children are told that a generous person, named Santa } \\
\text { Clause, brought them all the gifts like toys and cookies on Christmas eve." ( Student 3) } \\
\text { "Chinese dominate the Spring Festival celebration with some traditional beliefs that dictate what clothes } \\
\text { (such as new ones) and what color (such as red) to wear, when to eat certain foods on Spring Festival; for } \\
\text { example, on New Year's day, dumplings must be eaten. But Americans are free to wear and eat whatever } \\
\text { they prefer on Christmas holiday." ( Student 1) } \\
\text { "Christmas is much short (only one day) while Spring Festival lasts for more than a week due to its } \\
\text { traditional activities. The themes of decorations for the two holidays also differ. The decorations on Spring } \\
\text { Festival are meant to bring good luck and drive away evil spirits, but the decorations for Christmas are used } \\
\text { to create a holiday atmosphere and not much meaning in them." ( Student 2) }\end{array}$ \\
\hline $\begin{array}{l}\text { Finding } 2 \\
\text { Being able to critically evaluate } \\
\text { and reflect on their own cultural } \\
\text { practice and that of others. }\end{array}$ & $\begin{array}{l}\text { "During the Spring Festival, family bound is very important, but it seems like in our current generation } \\
\text { Christmas is more about money and presents other than family. Although Spring Festival is also losing some } \\
\text { traditions due to the younger generations, its significance still surpasses Christmas in America. "(Student 1) } \\
\text { "When the Chinese spend the Spring Festivals with the family and have good food and make memories, the } \\
\text { focus is on the true meaning of the history behind the holiday and pass it on to the younger generation. While } \\
\text { Americans really don't focus on much, other than the food and football, and a large portion don't even } \\
\text { understand the history of the holiday. What I learned from this is that 1) Americans need to learn about their } \\
\text { history prior to celebrating a holiday, and 2) the Chinese have done well to preserve the festival's history and } \\
\text { promote cultural awareness for future generation." ( Student 3) }\end{array}$ \\
\hline
\end{tabular}

The findings here tend to support Hoff's (2013) study that shows a course cultural project of reading fiction chosen from the target language culture in his FL classroom can foster "the students' conscious recognition of new cultural knowledge and competence and the process which has led them to this new level of achievement" (p. 47). He claims that, at the end of the project, the students should exhibit the ability to put new knowledge into a wider context, which entails both a better understanding of the foreign culture (the 'Other') and a heightened perception of the students' own identity and culture ('Self'). Our findings also support Hoff's insight since it is evident that writing comparing cultural essays helped students not just look at the surface similarities and differences between the Chinese and American cultures but dig deeper to see how the world views such as values and beliefs under them affect people in both cultures to behave in a certain way. Furthermore, the findings tend to agree with Su's (2011) study that reveals her use of a course cultural portfolio project in her college EFL class can help students shift from an ethnocentric view, show more respects to cultural differences, and increase awareness of the their own cultural limitations.

\section{B. Findings for and Discussion on Research Question 2}

Research Question 2: Can this course cultural research project help promote students' language skills?

The data analysis from students' PowerPoint oral presentations produced the finding classified as category 3, "The Target Language Skills Reinforced through the PPT Oral Presentations.” This finding demonstrates that doing PPT research presentations improves students' language ability in the aspects of speaking and listening in Chinese and of learning new vocabulary in both Chinese Pinyin and Chinese Characters. This is because that during the oral presentations, students were required to speak as much Chinese as they could while they were allowed to use English to communicate the main messages. In order to do a good job in both Chinese and English during the 15 minute presentations, the students had to spend plenty of time practicing by themselves, which offered them more opportunities to speak the target language, Mandarin Chinese. Since the PPT oral presentation was also a research project, the students went beyond their textbooks and learned new vocabulary from studying and presenting different cultural topics. Additionally, during the oral presentations, all the students in the class were engaged in listening to each other attentively so as to understand and follow the presentations. Thus, everyone had some practice in his or her target language listening and in encountering new vocabulary in Mandarin Chinese. TABLE 5 displays some of the new vocabulary the students acquired from doing different cultural topics. 
TABLE 5

THE SAMPLEs OF NEW VOCABUlaries ACQUiRED FROM STUDENT PPT ORAL PRESENTATIONS

\begin{tabular}{|c|c|}
\hline Cultural Topics & New Vocabularies in both Chinese Pinyin and Chinses Characters \\
\hline $\begin{array}{l}\text { Chinese Medicine and } \\
\text { Western Medicine }\end{array}$ & 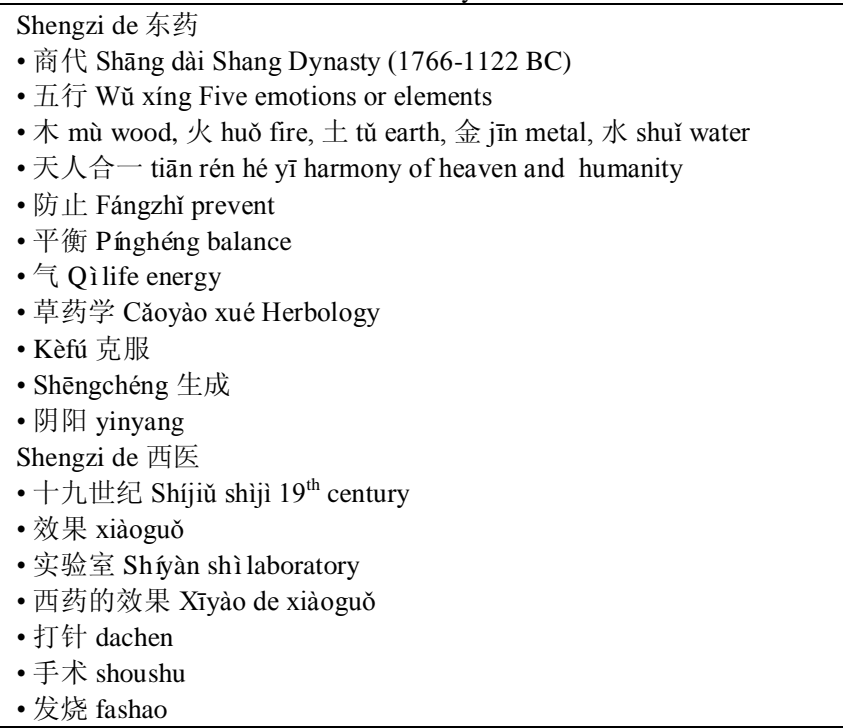 \\
\hline $\begin{array}{l}\text { Chinese Spring Festival } \\
\text { and American Christmas } \\
\text { Holiday }\end{array}$ & 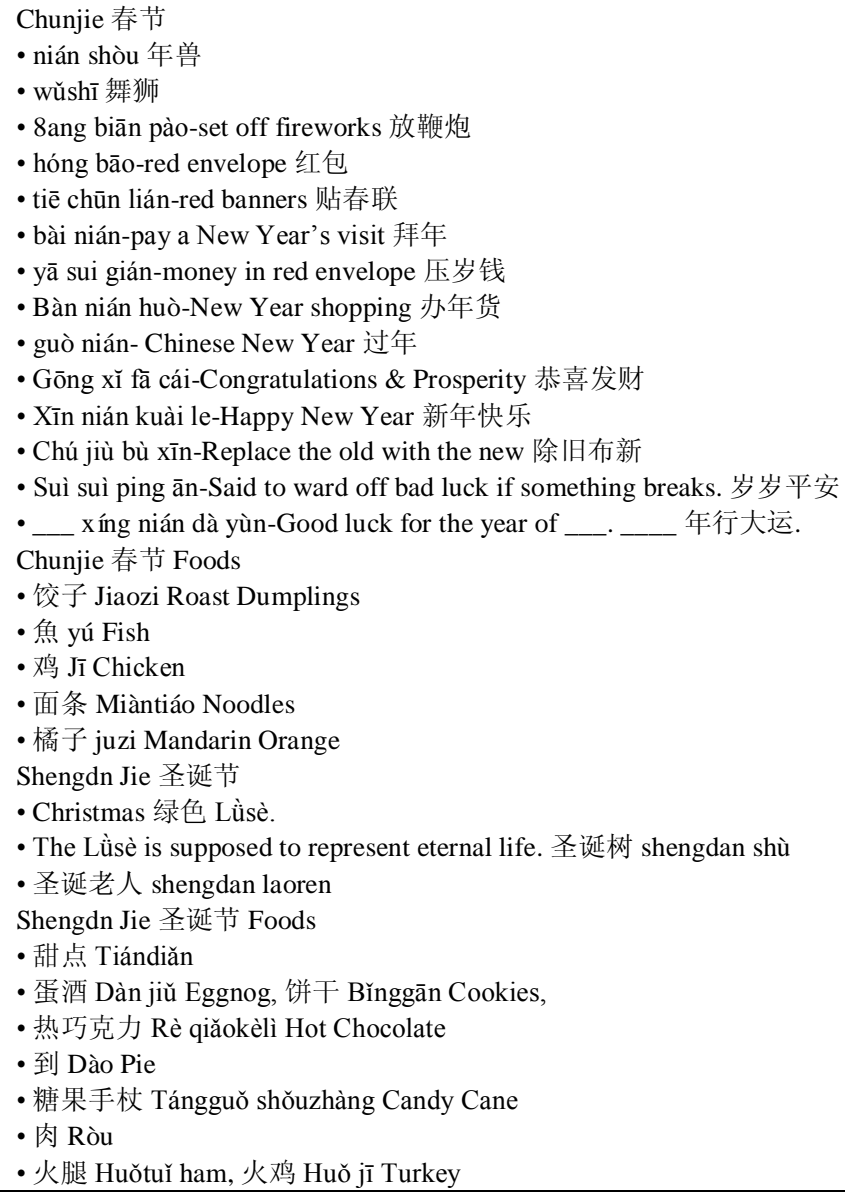 \\
\hline
\end{tabular}

The findings displayed in TABLE 5 further illustrate that the oral presentations offer students learning opportunities for both cultural content and language learning. They tend to support Tsou's (2003) study that concludes that, when cultural lessons were integrated into EFL instruction, students' language proficiency could be significantly improved, and students could become more interested in language learning.

\section{CONClusion}

This article has explored whether using a cultural research course project can positively impact foreign language students' intercultural competence and language learning. We can conclude that it is beneficial and helpful for foreign 
language teachers to use such a course research project to promote not only language students' intercultural competence but also their linguistic competence.

Through doing the project, the students improved their intercultural competence in that they have a more positive attitude towards "otherness," enriched their cultural knowledge of the target language society and that of their own, and obtained skills in critically appreciating and evaluating both similarities and differences between the target language culture and their own. Meanwhile, via the project, the students also expanded their language learning experience beyond their classroom and their textbooks and acquired more language skills in listening, speaking, and writing Chinese characters while they became more interested in and motivated by learning the target language and its culture.

Finally, the study shows that the cultural research course project helped the language teachers and students to meet the national cultural objectives for 21 century language education in the USA, which expect students to be able to demonstrate an awareness of the relationship among the practice, products, and perspectives of the target culture and to understand the concept of culture development through comparison between the target culture and their native culture (National Standards, 2006). As Hoff (2013) argues, "it is important to keep in mind, however, that the development of intercultural competence is a complex and time consuming endeavor" (p.46) for foreign language education. We recommend that in a future study, we might try to recruit additional language students to participate in a similar course research project to enrich the research data. We also suggest that a future study consider incorporating more qualitative research methods such as focus group discussions or individual interviews for analyzing some in depth individual opinions or thoughts about intercultural awareness and cultural diversity in foreign language teaching and learning.

\section{REFERENCES}

[1] ACTFL. (2006). Standards for foreign language learning in the $21^{\text {st }}$ century ( $3^{\text {rd }}$ ed.). Yonkers, NY: National Standards in Foreign Language Education Project.

[2] Bryam, M., Adam, N. \& David, S. (2001). Introduction. In M. Bryam, N. Adam \& S. David (Ed.), Language for intercultural communication and education, 1: Developing intercultural competence in practice (pp.1-7). Clevedon, GBR: Multilingual Matters.

[3] Byram, M. (1997). Face to face: Learning-and-culture through visits and exchanges. London: CILT.

[4] Bryam, M. (2009). Chapter 18Intercultural competence in foreign languages: The intercultural speaker and the pedagogy of foreign language education. In D. K. Deardorff (Ed.), The SAGE handbook of intercultural competence (pp.321-331). Thousand Oaks, CA: SAGE.

[5] Byram, M. \& Morgan, C. (1994). Teaching-and-learning-language-and-culture. Multilingual Matters No. 100. Clevedon: Multilingual Matters.

[6] Byram, M. \& Zarate, G. (1997). Definitions, objectives and assessment of sociocultural competence. In M. Byram, G. Zarate, \& G. Neuner (Eds.), Sociocultural competence in language learning and teaching (pp. 9-39). Strasbourg: Council of Europe.

[7] Catrinel, S. (2011). In pursuit of intercultural awareness and the 'procrustean bed' of EFL-Teaching." Lucrari Stiintifice, 54(2), 450-456.

[8] Council of Europe. (2001). The common European framework of reference for languages: Learning, teaching, assessment. Strasbourg: Council of Europe Publishing.

[9] Furstenberg, G. (2010). Making culture the core of the language class: Can it be done? The modern language journal, 94(ii), 329-332.

[10] Hoff, H. E. (2013). 'Self and other' in meaningful interaction: Using fiction to develop intercultural competence in the English classroom. Tidsskriftet FoU i Praksis, 7(2), 27-50.

[11] Kramsch, C. (1993). Context and culture in language teaching. Oxford: Oxford University.

[12] Kramsch, C. (1998). The privilege of the intercultural speaker. In M. Byram \& M. Fleming (Eds.), Language learning in intercultural perspective (pp. 16-31). Cambridge: Cambridge University Press.

[13] Tsou, W. (2005) The effects of cultural instruction on foreign language learning. RELC, 36(1), 39-57. DOI: $10.1177 / 003368820505348$.

[14] Scarino, A. (2010). Assessing intercultural capability in learning language: A renewed understanding of languages, culture, learning, and the nature of assessment. The modern Language journal, 94(ii), 324-329.

[15] Su, Y.C. 2011). The effects of the cultural portfolio project on cultural and EFL learning in Taiwan's EFL College classes. Language teaching research, 15(2), 230-250. DOI: 10.1177/1362168810388721.

Fang Li is a lecturer at the School of Translation Studies at Xi'an International Studies University, China. He obtained a Ph.D. degree in Instructional Leadership from the University of Alabama, USA, with a concentration in instructional technology in 2016. He also received his Med in Literacy/TESL in 2008 from University of Cincinnati, USA. His research interests include educational technology in language education, translation and interpretation education, and virtual learning.

Yingqin Liu is an associate professor in the Department of English and Foreign Languages at Cameron University, U.S.A. She was granted a doctoral degree in Technical Communication and Rhetoric from Tech Taxes University in 2007. She obtained her MA in English, with a concentration in TESL from Western Kentucky University in 2002. Her major research interests are in the theories and practice of intercultural communication and rhetoric, business communication, and second language teaching and writing. She has published scholarly articles in these areas. 